\title{
Kekuatan Putusan Badan Penyelesaian Sengketa Konsumen Terkait Keberatan dan Pembatalan Putusan Arbitrase Sebagai Alternative Dispute Resolution dalam Penyelesaian Sengketa Konsumen
}

\author{
Surya Muhammad Gunarsa \\ Program Magister Ilmu Hukum Universitas Padjadjaran, Bandung, Indonesia \\ E-mail: suryamhmmd@icloud.com
}

\begin{abstract}
Consumer dispute can be resolved by litigation and non-litigation based on agreement of the parties. Presence of the Consumer Dispute Resolution Agency (BPSK) considered as a new hope for parties because thats's give an option to resolve consumer dispute, through BPSK it is expected that dispute can be resolved in a simple, fast, and low-cost manner. However, in fact the verdict issued by BPSK has the disadvantage of not having specificity, it caused by the article 54 point 3 of Consumer Protection Law mention that the BPSK decision is final and binding but can still be submitted for objection, even cancellation, then the absence of executorial power on the BPSK decision causes this $B P S K$ decision to have no merit.
\end{abstract}

Keywords: Arbitration; BPSK; Consumer; Court Decision; Dispute.

\section{A. PENDAHULUAN}

Sengketa merupakan kondisi dimana terjadi pelanggaran terhadap persetujuan atau kesepakatan oleh salah satu, ataupun kedua belah pihak yang tertuang didalam kontrak baik secara sebagian maupun keseluruhan lalu timbul perselisihan diantara para pihak akibat terjadinya pelanggaran tersebut yang dikenal dengan istilah wanprestasi.

Di Indonesia, menyelesaikan sengketa khususnya di dalam bidang hukum perdata terdapat dua metode yaitu litigasi dan non-litigasi. Litigasi merupakan suatu proses penyelesaian sengketa yang dilakukan melalui lembaga peradilan negara, sehingga sengketa ini akan ditangani oleh hakim pengadilan di dalam suatu rangkaian persidangan yang dalam hal ini dilaksanakan oleh Mahkamah Agung dan lembaga peradilan dibawahnya.

Pengadilan sebagai suatu lembaga di dalam kekuasaan kehakiman bertugas untuk menerima, memeriksa serta mengadili setiap sengketa yang diajukan guna menegakan hukum dan keadilan yang berdasarkan pada Pancasila demi terselenggaranya negara 
hukum di Republik Indonesia. ${ }^{1}$

Penyelesaian sengketa secara litigasi memiliki kelebihan yaitu putusannya yang memiliki sifat final dan menciptakan kepastian hukum dengan meciptakan posisi win or lose position bagi para pihak, serta putusannya dapat dipaksakan pelaksanaannya jika pihak yang kalah tidak mau melaksakanan isi dari putusan pengadilan (eksekusi). ${ }^{2}$ Pada dasarnya, putusan pengadilan memiliki keistimewaan sebagai sarana penyelesaian sengketa secara litigasi yaitu putusan pengadilan memiliki sifat mengikat, kekuatan pembuktian, dan kekuatan memaksa pelaksaanaan putusan (eksekutorial). ${ }^{3}$

Senada dengan penjelasan sebelumnya, dalam menyelesaikan sengketa terdapat opsi Non-litigasi yang merupakan suatu metode alternatif penyelesaian sengketa diluar jalur pengadilan yang dapat ditempuh oleh para pihak, alternatif dalam penyelesaian sengketa ini dasarnya lahir dari masyarakat yang mengimpikan suatu prosen peradilan yang sederhana, cepat, dan memiliki biaya yang ringan. Penyelesaian sengketa melalui non-litigasi ini menjadi suatu opsi yang sangat diperhitungkan oleh pelaku bisnis karena kurangnya ke efektifan jika melalui proses litigasi guna mendapat keadilan. ${ }^{4}$

Indonesia sudah mengatur mengenai alternatif dalam penyelesaian sengketa melalui Undang-Undang Nomor 30 Tahun 1999 tentang Arbitrase dan Alternatif Penyelesaian Sengketa (UU Arbitrase) dalam UU Arbitrase disebutkan bahwa metode penyelesaian sengketa non-litigasi bisa dilakukan dalam beberapa bentuk yaitu Arbitrase, Negosiasi, Mediasi, Konsiliasi, dan Penilaian ahli. ${ }^{5}$

Salah atu lembaga penyelesaian sengketa secara non-litigasi adalah Badan Penyelesaian Sengketa Konsumen (BPSK), BPSK merupakan lembaga yang meyelesaikan sengketa konsumen antara pelaku usaha dengan konsumen,di dasari oleh Undang-Undang Nomor 8 tahun 1999 tentang Perlindungan Konsumen (UUPK) metode penyelesaian sengketa yang dilakukan oleh BPSK yaitu menggunakan pihak ketiga yang berperan sebagai penengah diantara keduabelah pihak yang bersengketa,. Pihak ketiga ini haru berposisi netral dan tidak memihak, cara yang dapat dilakukan oleh BPSK diantaranya Arbitrase, Mediasi, dan konsiliasi.

Penyelesaian sengketa melaui BPSK bukanlah suatu keharusan karena BPSK merupakan lembga yang memberikan alternatif dalam menyelesaikan sengketa konsumen dan merupakan pilihan dari para pihak. Pasal 54 ayat 3 UUPK menyebutkan bahwa setiap putusan BPSK bersifat final dan mengikat, final disini diartikan bahwa penyelesaian sengketa sudah berakhir, sedangkan mengikat diartikan sebagai memaksa dan merupakan sesuatu yang harus dijalankan oleh pihak yang diwajibkan, terdapat prinsip res judicata veritate hebetur, yang menyatakan suatu putusan tidak mungkin untuk dilakukan lagi upaya hukum, namun ketika di kaitkan dengan Pasal 56 ayat 2 dan Pasal 58 ayat 2 UUPK menegaskan bahwa terkait putusan BPSK yang bersifat final dan mengikat diajukan keberatan kepada Pengadilan Negeri dan terhadap putusan tersebut dapat diajukan kasasi ke Mahkamah Agung.

1 Rosita. (2017), “Alternatif Dalam Penyelesaian Sengketa (Litigasi Dan Non Litigasi)”, AlBayyinah of Islamic Law, Volume I Nomor 2, Desember, h.100. http://dx.doi.org/10.35673/albayyinah.v1i2.20.

2 Rosita, Ibid. h. 101

3 Mertokusumo, Sudikno. (1993), Hukum Acara Perdata Indonesial (Cet. I), Yogyakarta: Liberty, , h. $177-182$.

4 Sudirto, Zaeni Asyhadie. (2004), Mengenai Arbitrase Salah Satu Alternatif Penyelesaian Sengketa Bisnis, Jakarta: RajaGrafindo Persada, h. 11.

5 Pasal 1 ayat 1 dan 10 UU Arbitrase. 
Pada pelaksanaanya upaya BPSK dalam memberikan kepastian hukum bagi konsumen tidak dapat terpenuhi karena jika menyelesaikan sengketa melalui jalur nonlitigiasi yaitu BPSK, pada akhirnya harus menempuh jalur litigasi juga melalui pengadilan. Permasalahan lainnya juga timbul karena UUPK tidak menegaskan secara limitatif mengenai keberadaan mengenai keberatan dalam putusan BPSK, implementasi dari dari instrumen keberatan ini rasanya sangat kompleks dan membingunkan sehingga menimbulak multi interpretasu terutama bagi hakim dan lembaga peradilan terkait sehingga timbul multi tafsir terhadap maksud pada undang-undang,

Dari pemaparan diatas, akan dibahas mengenai permasalahan tentang bagaiamana kekuatan putusan arbitrase yang dikeluarkan oleh BPSK terkait keberatan dan pembatalan kepada putusan BPSK.

\section{B. METODE PENELITIAN}

Metode penelitian yang digunakan yang digunakan dalam penulisan artikel ini adalah metode peneletian kepustakaan, atau yang biasa dikenal metode penelitian hukum normatif. Implementasi dari metode ini adalah melakukan penelitian dengan meneliti bahan pustaka atau data sekunder sebagai penunjang penelitian. ${ }^{6}$ Bahan-bahan penelitian berupa bahan primer yaitu Peraturan Perundang-undangan utamanya adalah UndangUndang Nomor 30 Tahun 1999 tentang Arbitrase dan Alternatif Penyelesaian Sengketa, Undang-Undang Nomor 8 tahun 1999 tentang Perlindungan Konsumen, putusan pengadilan, serta peraturan lain yang dirasa relavan dengan penulisan artikel ini. Selanjutnya bahan hukum sekunder yang berupa buku, jurnal ilmiah, artikel elektronik dan tulisan-tulisan terkait. Semua bahan tersebut akan dipelajari serta dilakukan analisis dengan penjabaran yang bersifat deskriptif analistis dan terakhir akan ditarik kesimpulan dan saran sebagai jawaban atas permasalahan dalam penelitian ini.

\section{PEMBAHASAN}

\section{Arbitrase}

Dari sekian banyak pilihan metode alternatif dalam menyelesaikan sengketa khususnya sengketa bisnis, arbitrase merupakan alternatif yang paling populer selain karena dirasa lebih efektif, penyelesaian dengan arbitrase juga bersifat rahasia sehingga para pelaku usaha lebih senang karena sengketa yang menimpanya tidak diketahui khalayak banyak yang berpengaruh kepada kredibilitas perusahaan dan kemungkingkan akan berkurangnya pendapatan karena sengketa yang dialaminya. ${ }^{7}$

Lebih jauh mengenai arbitrase, arbitrase merupakan suatu istilah yang menggambarkan suatu tata cara berdamai atau sebagai penyediaan sarana berdamai dari suatu sengketa yang timbul sehingga mencapai suatu hasil tertentu yang secara hukum bersifat final dan mengikat. ${ }^{8}$

Pasal 1 butir 1 UU Arbitrase menegaskan bahwa arbitrase adalah "cara penyelesaian

6 Soekanto, Soerjono dan Mamuji, Sri. (2010). Penelitian Hukum Normatif Suatu Tinjauan Singkat, Jakarta: RajaGrafindo Persada, h.13-14

7 Adminbpl, "Ini Alasan Penyelesaian Sengketa Arbitrase Menjadi Populer Di Dunia Bisnis", https://bplawyers.co.id/2016/08/29/penyelesaiansengketaarbitrase/, (diakses pada 13/03/2019).

8 Prabowo, Tri Ari dan Nazriyah, R. (2017) "Pembatalan Putusan Arbitrase oleh Pengadilan dalam Putusan Mahkamah Konstitusi Nomor 15/PUU-XII/2014”, Jurnal Konstitusi, Volume 14, Nomor 4, Desember. h, 705. 
suatu sengketa perdata diluar pengadilan umum yang didasarkan pada perjanjian arbitrase yang dibuat secara tertulis oleh para pihak yang bersengketa", frasa tersebut menyebutkan "dibuat secara tertulis" sehingga dapat disimpulkan bahwa penyelesaian sengketa melalui arbitrase harus didasarkan pada perjanjian terlebih dahulu sebelum terjadi sengketa atau setelah sengketa terjadi. Hal tersebut tergambarkan di prosedur penyelesaian sengketa pada Badan Penyelesaian Sengketa Konsumen (BPSK) yang tertuang melalui form penandatanganan kesepakatan cara penyelesaian sengketa melalui forum arbitrase oleh kedua belah pihak yang bersengketa.

Melihat berbagai klasifikasi, maka arbitrase dapat di klasifikasikan sebagai berikut: ${ }^{9}$

a) Menurut Kekuatan Putusan

Menurut kekuatan putusannya arbitrase dapat dibagi kedalam dua tipe, yaitu binding dan non binding. Binding Arbitration pada prinsipnya merupakan arbitrase dengan keputusan yang bersifat final dan tetap. Ini mirip dengan keputusan pengadilan konvensional tingkat terakhir. Sedangkan non binding arbitration yang sering juga disebut sebagai advisory arbitration ini mirip dengan prosedur fact finding. Dalam hal ini, para pihak yang bersengketa bersama-sama memilih pihak ketiga untuk menerima atau menolak keputusan yang bersangkutan.

b) Lingkup Tugas

Dalam hal ini arbitrase dibagi menjadi interest arbitration dan rights arbitration. Dalam interest arbitration bukannya hak yang dipersengketakan yang mesti diputus, tetapi para pihak memakai jasa mereka untuk menciptakan provisiprovisi dari kontrak yang telah mengalami jalan buntu. Sedangkan rights arbitration lebih kepada pembelaan terhadap hak-hak para pihak yang bersengketa.

c) Inisiatif berarbitrase

Pada umumnya beracara dengan memakai arbitrase dipilih atas inisiatif para pihak yang bersengketakan melalui suatu kontrak yang dibuat sebelum atau setelah terjadi sengketa. Ini yang disebut voluntary arbitration. Namun demikian dalam bidang-bidang tertentu, pemilihan arbitrase memang diwajibkan oleh undang-undang (compulsory arbitration). Terkadang ini disebut juga quasi peradilan, seperti P4D dan P4P atau PPHI dalam bidang perburuhan.

d) Tempat Persetujuan Berarbitrase

Klasifikasi ini pada umumnya lebih didasarkan pada persetujuan tersendiri yang khusus untuk itu, oleh RV disebut akta kompromis seperti yang telah disebutkan diatas. Badan-badan pengadilan di Indonesia lebih banyak memutuskan dengan bernalar "naif" daripada "reasonable." Oleh karena itu dibentuklah arbitrase secara insidental dan khusus untuk menangani perkara yang bersangkutan. ini yang akan ditunjuk oleh para pihak yang bersengketa dan ada pula yang ditunjuk oleh hakim. Setelah keputusan diberikan maka tugas mereka selesai, dan mereka bubar.

e) Jenis Objek Sengketa

Jika dilihat dari jenis obyek yang dipersengketakan dan arbitrase diminta untuk menengahinya, maka suatu arbitrase dapat dibedakan menjadi :

1) Arbitrase Kualitas

9 Fuadi, Munir. (2006), Arbitrase Nasional: Alternatif Penyelesaian Sengketa Bisnis, Bandung: Citra Aditya Bakti, h. 61. 
Adalah suatu arbitrase yang menyangkut dengan fakta-fakta sehingga arbitrase harus jeli memilah-milah fakta tersebut serta menginterpretasi dan menganalisisnya.

2) Arbitrase Teknis

Adalah suatu arbitrase yang menyangkut hal-hal yang timbul dari penyusunan dan penafsiran kontrak.

3) Arbitrase Campuran

Adalah suatu campuran antara arbitrase yang berkenaan dengan fakta dan arbitrase yang berkenaan dengan hukum.

f) Arbitrase Khusus

Arbitrase khusus yang dikenal di Indonesia dikenal antara lain :

1) Arbitrase Khusus Muamalat.

2) Arbitrase Khusus Di bidang Perdagangan.

3) Arbitrase Khusus di bidang Ketenagakerjaan.

4) Arbitrase Khusus di bidang Lingkungan Hidup.

Segketa antara konsumen dengan pelaku usaha diatur dalam BAB $\mathrm{X}$ tentang Penyelesaian Sengketa yang tercantum dalam Pasal 45 sampai dengan Pasal 48 UUPK. Pasal 45 ayat (2) menyebutkan bahwa "penyelesaian sengketa konsumen dapat ditempuh melalui pengadilan atau diluar pengadilan berdasarkan pilihan sukarela para pihak yang bersengketa.'Dalam ayat (4) juga disebutkan bahwa upaya penyelesaian sengketa diluar pengadilan, gugatan melalui pengadilan hanya dapat ditempuh apabila upaya tersebut dinyatakan tidak berhasil oleh salah satu pihak atau oleh para pihak yang bersengketa. Oleh karenanya akan lebih baik jika para pihak memilih menyelesaikan sengketa konsumen melalui jalur alternatif atau melalui forum arbitrase.

\section{Badan Penyelesaian Sengketa Konsumen}

Pembentukan Badan Penyelesaian Sengketa Konsumen (BPSK) didasari atas penindaklanjutan dari dibentuknya Undang-Undang Nomor 8 tahun 1999 tentang Perlindungan Konsumen (UUPK). UUPK membentuk suatu lembaga untuk melindungi konsumen yaitu BPSK. Dalam Pasal 1 butir 11 disebutkan bahwa "BPSK adalah badan yang bertugas menangani dan menyelesaikan sengketa antara pelaku usaha dan konsumen." Tujuan utama sebenarnya dari BPSK adalah menyelesaikan sengketa konsumen yang sifatnya kecil dan sederhana.

Berdasarkan ketentuan pada Pasal 52 huruf a UUPK, ditegaskan bahwa tugas dan wewenang BPSK adalah melaksanakan penanganan dan penyelesaian sengketa dengan cara melalui mediasi atau arbitrasi atau konsiliasi. Tata cara penyelesaian sengketa konsumen melalui BPSK diatur dalam Surat Keputusan Menteri Perindustrian dan Perdagangan No. 350/MPP/Kep/2001.

Penyelesaian sengketa konsumen oleh BPSK dan menggunakan Arbitrase dilakukan oleh majelis yang dibentuk oleh ketua BPSK, majelis tersebut bertindak sebagai arbiter. Jumlah dari majelis tersebut berjumlah ganjil, paling sedikit 3 (tiga) orang, yang di dalamnya memuat peran sebagai pemerintah, pelaku usaha, dan konsumen.

Penyelesaian Sengketa konsumen harus dilaksanan paling lambat 21 hari kerja, yang dihitung semenjak permohonan di terima oleh BPSK. Sifat final dan mengikan putusan BPSK tertuang dalam Pasal 54 ayat 2 UUPK, dan putusan tersebut dijatuhkan dalam tenggang waktu 21 hari semenjak gugatan diterima oleh BPSK (Pasal 55 UUPK 
jo Pasal 38 SK 350/MPP/Kep/2001).

Pasal 40 SK Menperindag No. 350/MPP/Kep/21/2001, menegaskan bahwa amar dari putusan yang dikeluar BPSK hanya terbatas pada 3 alternatif, yaitu :

1) Perdamaian

2) Gugatan ditolak

3) Gugatan dikabulkan

Dalam amar putusan, jika gugatan dikabulkan maka akan ditetapkan kewajiban bagi pelaku usaha untuk melakukan :

1) Ganti rugi atas kerusakan, pencemaran dan atau kerugian konsumen akibat mengkonsumsi barang dan atau memanfaatkan jasa.

2) Sanksi administratif, dalam Pasal 60 UUPK merupakan hak khusus bagi BPSK sebagai lembaga alternatif, dalam Pasal 60 ayat (2) jo pasal 60 ayat (1) UUPK, sanksi administratif yang dapat dijatuhkan oleh BPSK adalah berupa penetapan ganti rugi sampai setinggi-tingginya Rp. 200.000.000,- (dua ratus juta rupiah) bagi pelaku usaha yang melakukan pelanggaran terhadap atau dalam rangka tidak dilaksanakannnya pengembalian ganti rugi

\section{Keberatan dan Pembatalan Putusan Badan Penyelesaian Sengketa Konsumen}

BPSK sebagai quasi badan peradilan dalam menangani sengketa-sengketa konsumen pada hakikatnya memiliki kewenangan dalam hal menangani, menyelesaikan dan memutus sengketa konsumen. Pasal 54 ayat 3 UUPK menegaskan bahwa Putusan dari majelis BPSK memiliki sifat final dan mengikat, namun demikian baik konsumen maupun pelaku usaha yang merasa tidak puas dengan putusan BPSK bisa mengajukan keberatan kepada Pengadilan Negeri paling lambat 14 hari kerja setelah menerima pemberitahuan putusan tersebut, dasar dari perbuatan hukum tersebut adalah Pasal 56 ayat 2 UUPK jo Pasal 41 ayat 3 Kepmenperindag RI Nomor 350/MPP/Kep/12/2001. Bagi pihak yang yang tidak melakukan keberatan dalam tenggang waktu tersebut, dianggap menerima putusan tersebut dan berkewajiban melaksanakan putusan tersebut paling lambat 5 hari kerja setelah batas pengajuan keberatan telampaui (Pasal 56 ayat 3 UUPK jo Pasal 41 ayat 5 Kepmenperindag RI Nomor 350/MPP/Kep/12/2001).

Lembaga yang menangani keberatan dalam suatu putusan dalam hukum Belanda dikenal dengan beroep, lembaga beroep biasanya menangani kasus keberatan yang berhubungan dengan penetapan (beschikking) terhadap perizinan (vergunning) dalam lingkum Hukum Administrasi. Sehingga dapat di artikan bahwa beroep ini merupakan sejenis lembaga banding dalam hukum administrasi. Dalam lembaga peradilan umum disebut dengan banding terhadap putusan pertama atau pengadilan negeri. ${ }^{10}$

Permasalahan timbul ketika setelah pihak yang bersengketa menerima pemberitahuan atas putusan BPSK lalu mengajukan keberatan di Pengadilan Negeri. Permasalahan ini muncul karena UUPK tidak mengakomodiir secara limitatif lingkup keberatan terhadap putusan BPSK ini, penerapan dari upaya hukum keberatan ini membingungkan dan menimbulkan multi interpestasi khususnya bagi para hakim. Hal tersebut terjadi karena makna dari "Keberatan" sejatinya tidak dikenal dalam lingkup hukum acara yang ada, sehingga timbul pertanyaan bahwa, apakah upaya keberatan harus diajukan dalam acara gugatan, perlawanan atau permohonan? Lalu apakah perlu atau

10 Siahaan, NHT. (2005), "Hukum Konsumen (Perlindungan Konsumen dan Tanggung Jawab Produk)", Bogor: Panta Rei, h. 213 
tidak BPSK menjadi turut digugat agar keterangannya dapat didengar secara langsung.

Dapat diperhatikan bahwa UUPK menyimpangi ketentuan-ketentuan terkait peran lembaga peradilan, padahal ketentuan-ketentuan terkait lembaga peradilan memiliki implikasi hukum yang cukup signifikan. Penyimpangan tersebut terjadi karena ttidak diikuti dengan petunjuk teknis yang maupun penjelasan yang cukup, maka hal ini berdampak pada munculnya kendala-kendala yang memiliki urgensi dalam penyelesaiannya agar UUPK dapat berjalan dengan baik. ${ }^{11}$

Keputusan BPSK yang bersifat final dan mengingat tercantum dalam Pasal 54 ayat 3 UUPK jika dikaitkan dengan Pasal 56 ayat 2 rasanya sangat kontradiktif karena Pasal tersebut menyebutkan bahwa ada upaya hukum lain yaitu keberatan terhadap putusan BPSK yang dapat diajukan ke pengadilan, Selanjutnya Pasal 54 ayat (3) Undang-undang Perlindungan Konsumen mengatakan bahwa keputusan BPSK bersifat final dan mengikat, bahwa apabila ditafsirkan secara sistematis dengan ketentuan yang terdapat dalam HIR jo Undang-undang No. 27 tahun 1947 tentang Peradilan Ulangan, maka putusan pengadilan negeri yang belum mempunyai kekuatan hukum tetap, terhadap putusan pengadilan negeri yang telah mempunyai kekuatan hukum tetap, hanya dapat diajukan upaya hukum peninjauan kembali ${ }^{12}$. Karena ketidakpastian tersebut Mahkamah Agung merespon dengan mengeluarkan Peraturan Mahkamah Agung No. 1 tahun 2006 tentang Tata Cara Pengajuan Keberatan Terhadap Putusan Badan Penyelesaian Sengketa Konsumen (Perma No. 1 tahun 2006).

Perma No.1 tahun 2006 terbentuk karena UUPK tidak mengatur secara tegas terkait hukum acara dipengadilan negeri dalam hal mengajukan keberatan terhadap putusan BPSK dan tata cara eksekusi, dalam kaitannya dengan pengajuan keberatan atas putusan BPSK terhadap Pengadilan Negeri, terdapat perbedaan mengenai status BPSK yang bukan lagi sebagai pihak yang menjadi kuasa atas konsumen, tetapi BPSK adalah pihak diluar yang bersengketa.

Keberadaan Perma No.1 tahun 2006 yang mengacu pada UU arbitrase di harapkan dapat membantu Pengadilan Negeri dalam menangani kasus keberatan terhadap putusan BPSK, namun faktanya masih ada aturan yang menimbulkan ketidak pastian yang terdapat pada Perma no. 1 tahun 2006, salah satunya terdapat pada Pasal 6 ayat 2 Perma No.1 Tahun 2006 yang berbunyi: "pemeriksaan keberatan dilakukan hanya atas dasar putusan BPSK dan berkas perkara". Pasal tersebut sama saja dengan aturan banding pada perkara perdata biasa yang notabene nya hanya membutuhkan berkas perkara saja, namun pada kenyataannya pasal tersebut sulit diterapkan karena dalam Pasal 6 Ayat 3 Perma No.1 tahun 2006 dijelaskan bahwa :

"Keberatan terhadap putusan arbitrase BPSK dapat diajukan apabila memenuhi persyaratan pembatalan putusan arbitrase sebagaimana diatur dalam Pasal 70 Undang-Undang Nomor 30 Tahun 1999 tentang arbitrase dan alternatif penyelesaian sengketa, yaitu :

a) surat atau dokumen yang diajukan dalam pemeriksaan, setelah putusan dijatuhkan, diakui palsu atau dinyatakan palsu

b) setelah putusan arbitrase BPSK diambil ditemukan dokumen yang bersifat menentukan yang disembunyikan oleh pihak lawan; atau

11 Siallagan, Gabriel. (2013) “Analisis Yuridis Upaya Keberatan Terhadap Putusan Badan Penyelesaian Sengketa Konsumen Dalam Kaitannya Dengan Perlindungan Konsumen"Jurnal Nestor Magister Hukum, Volume 3 Nomor 5, h. 7

12 Siallagan, Gabriel. Ibid., h. 11-12. 
c) putusan diambil dari hasil tipu muslihat oleh salah satu pihak dalam pemeriksaan sengketa".

Dalam hal pembuktian terbukti apa tidaknya unsur-unsur pada Pasal 6 ayat 3 Perma No.1 tahun 2006 tersebut, terlebih dahulu harus melalui tahap pembuktian terlebih dahulu, pembuktian ini tentu saja membutuhan tahapan uji materil terhadap perkara, yang seharusnya hakim pada tahap banding/keberatan hakim hanya melakukan uji formil saja.

Selanjutnya, Pasal 6 ayat 5 Perma No.1 tahun 2006 menyebutkan bahwa :

"Dalam hal keberatan diajukan atas dasar alasan lain diluar ketentuan sebagaimana dimaksud ayat (3), majelis hakim dapat mengadili sendiri sengketa konsumen yang bersangkutan."

Bunyi pasal tersebut seakan-akan menganulir ayat 3 yang memuat unsur-unsur pembatalan putusan BPSK. Keberadaan ayat 5 ini dapat memberikan penafsiran bahwa putusan BPSK yang diajukan ke beratan di Pengadilan Negeri memiliki alasan lain diluar ayat 3, sehingga majelis hakim dapat mmengadili sendiri perkara sengketa konsumen yang terkait menggunakan hukum acara perdata, dan kebertan tersebut didaftarkan menggunakan nomor yang berbeda dengan dengan nomor putusan BPSK dengan konsekwensi BPSK dapat terlibat sebagai pihak tergugat ataupun turut tergugat.

Hal seperti diatas dialami oleh BPSK Kota Yogyakarta yang menjadi Turut Tergugat atas putusannya sendiri dalam perkara No.50/PDT.G/2007/PN.YK yang title gugatannya adalah "Gugatan/Keberatan atas Putusan Arbitrase BPSK.". Seharusnya, andaikata mengacu kepada Perma No.1 Tahun 2006, keberatan tersebut didaftarkan dengan nomor 04/Abs/BPSK-Yk/VI/2007 sebagai nomor putusan arbitrase BPSK Kota Yogyakarta.

Begitu pula dengan titel gugatan yang dibaca "gugatan atau keberatan" yang terlihat kabur atau bias (obsceur libel) karena sejatinya penggunakan istilah gugatan seharusnya tidak dapat disamakan dengan keberatan. Gugatan adalah salah satu cara untuk menyelesaikan sengketa konsumen, sedangkan keberatan merupakan upaya hukum bagi pihak yang menerima putusan BPSK Yogyakarta. ${ }^{13}$ Dengan demikian, dapat kita lihat bahwa terjadi penyimpangan terhadap perinsip peradilan cepat, sederhana, dan biaya ringan yang dianut lembaga peradilan secara umum lalu prinsip small claim procedure dalam penyelesaian sengketa konsumen.

Keterlibatan BPSK kota Yogyakarta sebagai pihak didalam upaya keberatan bertentangan dengnan Pasal 3 ayat 3 Perma no.1 tahun 2006 yang mengatakan bahwa "dalam diajukan keberatan, BPSK bukan merupakan pihak". Namun pada kenyataannya BPSK Kota Yogyakarta justru menjadi turut tergugat yang setelahnya diajukan eksepsi, ternyata eksepsi tersebut ditolak oleh majelis hakim.

BPSK Kota Yogyakarta seharusnya tidak dikenakan tanggung jawab hukum apapun karena bertindak sebagai arbiter, kecuali dalam tindakannya ada itikad tidak baik. Segala penafsiran mengenai keberatan yang ada atas putusan BPSK terjadi karena tidak ada ketegasan dari UUPK dalam memberikan titel hukum yang tepat kepada putusan BPSK sehingga perlu adanya penetapan dari pengadilan untuk mengeluarkan sifat eksekutorialnya, selanjutnya tidak ada pengaturan yang jelas dalam UUPK terhadap putusan BPSK apakah menguatkan, menolak, atau sebatas dijadikan alat bukti permulaan sebagaimana tercantum pada Pasal 56 ayat 5 UUPK $^{14}$

13 Putusan sela, NO. 50/PDT.G/2007/PN.YK, antara PT Saphir Yogya Super Mall melawan Yan Richo Nielson Purba dan Badan Penyelesaian Sengketa Konsumen Pemerintah Kota Yogyakarta, h. 38

14 Wulandari, Bernadetta T. (2006), "BPSK Sebagai Alternatif Upaya Penegakkan Hak Konsumen 
Selain keberatan, dalam sengketa konsumen khususnya yang diselesaikan melalui arbitrase dikenal pula pembatalan dalam putusan arbitrase, pembatal putusan arbitrase dapat diartikan sebagai upaya hukum yang dapat dilakukan oleh para pihak untuk meminta kepada Pengadilan Negeri agar suatu putusan arbitrase dibatalkan baik sebagian, maupun secara keseluruhan. ${ }^{15}$ Dalam proses pembatalan putusan arbitrase, pengadilan tidak memiliki kewenangan untuk memeriksa pokok perkara, keweanangannya haya terbatas pada pemeriksaan keabsahan prosedur pengambilan putusan arbitrase yang hanya merupakan proses pemilihan arbiter, hingga pemberlakukan hukum yang dipilih oleh para pihak dalam menyelesaikan sengketa. ${ }^{16}$

Pasal 70 UU Arbitrase diatur mengenai pembatalan putusan tersebut, Pasal 70 tersebut menyatakan ;

"bahwa terhadap putusan arbitrase para pihak dapat mengajukan permohonan pembatalan, jika putusan tersebut diduga mengandung unsur-unsur antara lain sebagai berikut :

a) Surat atau dokumen yang diajukan dalam pemeriksaan, setelah putusan dijatuhkan, diakui palsu atau dinyatakan palsu;

b) Setelah putusan diambil ditemukan dokumen yang bersifat menentukan, yang disembunyikan oleh pihak lawan;

c) Putusan diambil dari hasil tipu muslihat yang dilakukan oleh salah satu pihak dalam pemeriksaan sengketa."

Mengingat bahwa putusan arbitrase bersifat final and menginkat, maka dalam upaya permohonan pembatalan putusan arbitrase ini diatur dengan setegas mungkin. Hal ini tercermin dalam penjelasan Pasal 70 UU Arbitrase, yaitu:

"Permohonan pembatalan hanya dapat diajukan terhadap putusan arbitrase yang sudah didaftarkan ke Pengadilan. Alasan permohonan pembatalan putusan yang disebut dalam pasal ini harus dibuktikan dengan putusan pengadilan. Apabila pengadilan menyatakan bahwa alasan-alasan tersebut terbukti atau tidak terbukti, putusan pengadilan ini dapat digunakan sebagai dasar pertimbangan bagi hakim untuk mengabulkan atau menolak permohonan."

Dengan adanya syarat diatas, dapat kita simpulkan bahwa pembatalan suatu putusan arbitrase merupakan upaya hukum ekstra, yang dapat dilakukan apabila terjadi kecurangan dalam proses arbitrase. ${ }^{17}$ Namun, Mahkamah Konstitusi menghapus Penjelasan Pasal tersebut melalui Putusan Nomor 15/PUU/XII/2014. MK mengeluarkan putusan tersebut karena adanya permohonan uji materil terhadap penjelasan Pasal 70 UU Arbitrase. MK sepakat bahwa dalam penjelasaan Pasal 70 UU Arbitrase bertentangan dengan dengan maksud dari Pasal 70, dalam penjelasannya seakan timbul Norma baru, bukan menjelaskan mengenai bagian dari batang tubuh Pasal 70 UU arbitrase, selain itu terdapat unsur dugaan yang harus dibuktikan dengan putusan pengadilan.

Dugaan yang dimaksud adalah dugaan akan putusan arbitrase yang didasarkan pada hal-hal yang telah di tentukan secara limitatif dalam Pasal 70 UU Arbitrase sehingga jika Penjelasan Pasal 70 ini masih berlaku, jelas akan memberatkan dan merugikan pihak Pemohon. Hal ini karena dapat dipastikan batas waktu 30 hari untuk mengajukan

Di Indonesia", Gloria Juris, Volume 6 Nomor 2, h.

15 Fuady, Munir Op.Cit h. 10

16 Winarta, Frans Hendra. (2013), “Hukum Penyelesaian Sengketa”, Jakarta: Sinar Grafika, h. 85

17 Andriansyah, Muhammad (2014) "Pembatalan Putusan Arbitrase Nasional Oleh Pengadilan Negeri”, Jurnal Cita Hukum. Volume II No. 2, h. 
permohonan pembatalan arbitrase tersebut akan terlampui. Sehingga, akan mustahil suatu permohonan pembatalan putusan arbitrase diajukan dengan mendasarkan pada putusan pidana yang telah berkekuatan hukum tetap.

Selain syarat pembatalan putusan arbitrase didalam UU Arbitrase, terdapat juga syarat pembatalan di luar UU Arbitrase yaitu didalam Undang-Undang Nomor 48 Tahun 2009 tentang Kekuasaan Kehakiman (UU Kekuasaan Kehakiman) Pasal 10 ayat 1 disebutkan bahwa "Pengadilan dilaran menolak untuk memeriksa, mengadili, memutus perkara suatu perkara dengan dalih bahwa hukum tidak ada, atau kurang jelas, melainkan wajib memeriksa dan mengadilinya" terkait dengan pembatalan putusan arbitrase inipengaturan mengenai pembatalan tidak sulit untuk ditemui karena arbitrase sudah hidup dan berkembang dimasyarakat nasional maupun internasional sejak lama.

Di Indonesia, pengaturan terdapat Reglement op de Rechvondering (Rv), yaitu pengaturan mengenai perundang-undangnan yang berlaku pada zaman Hindia Belanda dan berlaku sampai ada UU Arbitrase, Rv dapat dijadikan sebagai referensi terkait nilainilai hukum yang berlaku di masyarakat terkait pembatalan putusan arbitrase. Didalam Pasal $643 \mathrm{Rv}$, mengatur mengenai pembatalan putusan arbitrase, terdapat 10 alasan yang dapat dijadikan suatu putusan arbitrase dianggap batal alasan-alasan tersebut adalah :

1) Putusan melampaui batas-batasan perjanjian arbitrase.

2) Putusan arbitrase diberikan berdasarkan suatu perjanjian arbitrase yang ternyata tidak sah atau gugur demi hukum.

3) Putusan arbitrase telah diberikan oleh arbiter yang tidak berwenang memutus tanpa kehadiran arbiter lainnya.

4) Telah diputuskan hal-hal yang tidak dituntut atau putusan telah mengabulkan lebih daripada yang dituntut.

5) Putusan itu mengandung hal-hal yang satu sama lain saling bertentangan.

6) Arbiter telah lalai memberikan putusan tentang satu atau beberapa hal yang menurut perjanjian arbitrase diajukan kepada mereka untuk diputus

7) Arbiter telah melanggar prosedur hukum acara arbitrase yang harus diikuti dengan ancaman kebatalan.

8) Telah dijatuhkan putusan berdasarkan surat-surat yang setelah putusan itu dijatuhkan, diakui sebagai palsu atau telah dinyatakan sebagai palsu.

9) Setelah putusan diberikan, surat-surat yang menemukan yang dulu disembunyikan oleh para pihak, ditemukan lagi.

10) Putusan didasarkan pada kecurangan atau itikad jahat, yang dilakukan selama jalannya pemeriksaan, yang kemudian diketahui.

Salah satu kasus terkait pembatalan putusan BPSK terjadi pada Putusan Arbitrase BPSK Bukittingi No 11/PTS- BPSK/BKT/X/2015 ${ }^{18}$ yang dibatalkan oleh Pengadilan Negeri Bukittingi dalam putusan Nomor 24/PDT.SUS-BPSK/2015/PN.BKT. Pengajuan keberatan oleh pemohon karena menggangap putusan BPSK telah merugikan pemohon yang dalam keberatanya pemohon menyebutkan bahwa BPSK telah melanggar Pasal 4 ayat 2 Kepmenperindag RI Nomor 350/MPP/Kep/12/2001 yaitu penyelesaian sengketa konsumen bukan merupakan proses penyelesaian sengketa secara berjenjang dan sidang majelis dilakukan secara tertutup.

Isi dari putusan tersebut adalah memutus bahwa putusan BPSK Bukittinggi batal

18 Putnado, Muhammad Gakhairi. (2017), "Kajian Hukum Pembatalan Putusan BPSK Nomor 11/PTS-BPSK/BKT/X/2015 Atas Upaya Hukum Keberatan Oleh Pihak Pelaku Usaha (Studi Kasus Putusan Pengadilan Negeri Bukittingi Nomor 24/PDT.SUS-BPSK/2015/PN.BKT)”, Diponegoro Law Journal, Volume 6, Nomor 2, h. 1. 
demi hukum, menbayar ganti rugi, serta membayar sanksi administratif. Yang menarik disini adalah dalam pertimbangan pembatalan yang dilakukan oleh Pengadilan Negeri Bukit Tinggi, tidak adanya syarat yang terpenuhi di dalam Pasal 70 UU Arbitrase,dan syarat yang tercantum pada Pasal 30 UU Kekuasaan kehakiman. lalu yang menjadi dasar pertimbangan Pengadilan Negeri membatalkan putusan BPSK Bukittingi adalah BPSK keliru dalam memahami pemeriksaan secara tertutup, karena pemeriksaan secara tertutup bukan berarti putusannya harus tertutup pula. Pembacaan putusan dalam sidang sifatnya terbuka untuk umum merupakan salah satu syarat keabsahan (syarat mutlak) dan mempunyai kekuatan hukum bagi suatu putusan, karena hal tersebut menunjukan sifat objektif pemeriksaan penyelesaian sengketa konsumen dan mengikatnya suatu putusan. ${ }^{19}$ Suatu putusan badan peradilan tidak akan ada artinya ketika tidak dapat dilaksanakan atau dengan kata lain tidak memiliki daya eksekutorialnya, seyogyanya suatu putusan yang sudah berkekuatan hukum tetap atau inkracht harus dapat dilakukan baik berdasarkan kesadaran, maupun secara paksa oleh alat-alan negara.

Eksekusi putusan perdata terbagi dalam dua jenis, yaitu eksekusi untuk menghukum pihak yang kalah untuk membayar sejumlah uang ${ }^{20}$, dan eksekusi yang menghukum orang untuk melakukan suatu perbuatan tertentu ${ }^{21}$. Kemudian eksekusi riil untuk memerintahkan pengosongan benda tetap, ${ }^{22}$ yang memberikan sifat eksekutorial suatu putusan baik putusan pengadilan ataupun putusan arbitrase adalah kepala putusan atau yang dikenal dengan irah-irah yang bunyinya "Demi Keadilan Berdasarkan Ketuhanan Yang Maha Esa". Irah-irah tersebut merupakan syarat yang mutlak agar memiliki nilai kekuatan yang sama dengan putusan pengadilan yang memiliki daya eksekutorial pada putusannya yang Inkracht.

Permohonan eksekusi dapat dilakukan terhadap putusan BPSK maupun putusan keberatan, namun dalam UUPK tidak mengakomodir pelaksanaannya, pelaksanaan dari putusan BPSK masih tergantung pada Pengadilan Negeri yang sebagai salah satu lembaga dalam kekuasaan kehakiman dan memiliki legimtimasi dalam memaksa suatu pelaksanaan putusan. Tata cara melaksanakan putusan diatur di dalam Pasal 195 HIR, UUPK dalam hal ini menjelaskan dalam Pasal 57 bahwa eksekusi dapat dimintakan penetapan eksekusinya kepada Pengadilan Negeri dimana konsumen, Ketentuan tersebut didukung pula oleh Kepmenridag No.350/MPP/12/2001 bahwa pihak yang mengajukan eksekusi adalah BPSK.

Kendala dalam permohonan pelaksanaan eksekusi putusan BPSK disebabkan karena didalam putusan BPSK tidak ada pencantuman irah-irah, berbeda dengan Putusan BPSK yang mencantumkan irah-irah, dalam Pasal 54 ayat 1 butir a UU Arbitrase menegaskan bahwa suatu putusan arbitrase harus memuat irah-irah "Demi Keadilan Berdasarkan Ketuhan Yang Maha Esa" sehingga jika tidak adanya pencantuman irah-irah ini mengakibatkan putusan menjadi batal demi hukum. ${ }^{23}$

Salah satu contoh bahwa ketidaan irah-irah dapat menghambat eksekusi putusan BPSK adalah BPSK Kota Bandung yang mengajukan fiat eksekusi kepada putusan BPSK yang bernomor 66/Pts-BPSK/VII/2005 ke PN Jakarta Pusat. PN Jakarta Pusat menyatakan jika putusan BPSK tersebut tidak dapat dilakukan eksekusinya karena tidak

19 Ibid, h. 10

20 Pasal 195 HiR atau Pasal 208 RBg

21 Pasal $225 \mathrm{HiR}$ atau Pasal $259 \mathrm{RBg}$

${ }^{22}$ Mertokusumo, Sudikno. (2005), "Faktor-faktor Yang Mempengaruhi Dan Menghambat Pelaksanaan Putusan Hakim (eksekusi) dalam Perkara Perdata”, Majalah ilmiah Ilmu Hukum Jatiswara, Fakultas Hukum Universitas Mataram, Vol.20, No.3, Juli, h. 336-337

23 Siallagan, Gabriel Op. Cit., h.18. 
tercantum irah-irah, yang mana dalam putusan BPSK tidak dikenal irah-irah ${ }^{24}$. PN Jakarta pusat melalui surat nomor W7.Db.Ht.04.10.3453.2005, yang intinya adalah menyatakan jika putusan BPSK tidak dapat diproses kerena tidak memenuhi persyaratan yaitu putusan BPSK harus memuat irah- irah irah "Demi Keadilan Berdasarkan Ketuhan Yang Maha Esa” sesuai dengan UU Arbitrase Pasal 54 ayat 1.

Didalam UUPK maupun Kepmenridag No.350/MPP/12/2001, tidak mengatur mengenai pencantuman irah-irah didalam putusan BPSK. Hal tersebut karena secara struktural BPSK berada dibawah Kementrian Perdagangan sedangkan HiR atau RBg dan UU Kekuasaan Kehakiman adalah untuk badan peradilan. Namun hal tersebut seharusnya bukanlah masalah karena BPSK merupakan salah satu quasi peradilan untuk menyelesaikan sengketa konsumen melalui arbitrase, sehingga dalam putusannya harus dicantumkan irah-irah "Demi Keadilan Berdasarkan Ketuhanan Yang Maha Esa" karena mengacu pada UU Arbitrase.

Terkait mengenai eksekusi putusan BPSK, berdasarkan Pasal 57 UUPK jo. SK Kepmenridag No.350/MPP/12/2001, eksekusi dapat dilaksanakan karena merupakan eksekusi khusus dan sejalan dengan asas lex specialis derogat legi genenalis, walaupun harus penetapan eksekusinya ke pengadilan negeri yang menjadi pertanyaannya adalah kontradiksi antara Pasal 57 UUPK jo. Pasal 42 SK Menperindag No. 350/MPP/Kep/12/2001 dengan ketentuan di dalam hukum acara perdata yaitu keharusan BPSK dalam mengajukan permohonan eksekusi ke pengadilan terhadap putusan yang dihasilkannnya, didalam hukum acara perdata, pengajuan permohonan eksekusi dilakukan oleh pihak yang menang sedangkan BPSK dalam hal ini merupakan lembaga yang menyelesaikan sengketa konsumen. Dalam hal ini BPSK selaku lembaga yang bersifat netral dan imparsial menjadi diragukan

\section{P E N U T U P}

Upaya penyeselaian sengketa konsumen melalui arbitrase oleh BPSK yang disediakan oleh UUPK belum mengakomodir pemenuhan hak-hak konsumen karena, BPSK merupakan lembaga yang terhitung masih baru sehingga berdampak pada pengaturan dalam hukum acaranya masih semrawut atau ambivalen baik UUPK, UU Arbitrase, SK Menperindag No. 350/MPP/Kep/12/2001 sehingga kurang dapat dijadikan acuan dalam menyelesaikan sengketa konsumen secara komprehensif, karena menimbulan multitafsir. lalu BPSK belum mencerminkan penyelesaian sengketa yang bersifat sederhana, cepat,mudah, dan biaya ringan karena terjadi kontradiksi antara sikap pengadilan dengan putusan BPSK yang merupakan putusan bersifat final dan mengikat.

Mengenai kekuatan putusan BPSK, selain tidak memiliki kekuatan eksekutorial karena tidak adanya irah-irah, lalu butuh penetapan untuk eksekusi terhadap putusannya, terkait dengan upaya keberatan dan pembatalan yang dapat dilakukan kepada putusan arbitrase oleh BPSK memberikan kesan bahwa putusan BPSK tidak memiliki sifat yang final dan mengikat, sehingga nampak Putusan BPSK tidak dianggap sebagai putusan yang memiliki kekuatan hukum, hal tersebut dapat dimanfaatkan bagi pelaku usaha untuk mengabaikan putusan yang dikeluarkan oleh BPSK..

${ }^{24}$ Nugroho, Susanti Adi. (2008), Proses Penyelesaian Sengketa Konsumen Di Tinjau dari Hukum Acara serta Kendala Implemen- tasinya, Jakarta: Kencana, h. 341 


\section{Buku}

[1] Fuadi, Munir. (2006), Arbitrase Nasional: Alternatif Penyelesaian Sengketa Bisnis, Bandung: Citra Aditya Bakti

[2] Mertokusumo, Sudikno. (1993), Hukum Acara Perdata Indonesial (Cet. I), Yogyakarta: Liberty.

[3] Nugroho, Susanti Adi. (2008), Proses Penyelesaian Sengketa Konsumen Di Tinjau dari Hukum Acara serta Kendala Implemen- tasinya, Jakarta: Kencana.

[4] Sudirto, Zaeni Asyhadie. (2004), Mengenai Arbitrase Salah Satu Alternatif Penyelesaian Sengketa Bisnis, Jakarta: RajaGrafindo Persada.

[5] Soekanto, Soerjono dan Mamuji, Sri. (2010). Penelitian Hukum Normatif Suatu Tinjauan Singkat, Jakarta: RajaGrafindo Persada.

[6] Siahaan, NHT. (2005), "Hukum Konsumen (Perlindungan Konsumen dan Tanggung Jawab Produk)", Bogor: Panta Rei.

[7] Winarta, Frans Hendra. (2013), “Hukum Penyelesaian Sengketa”, Jakarta: Sinar Grafika.

\section{Jurnal dan Lain-Lain}

[8] Andriansyah, Muhammad (2014) "Pembatalan Putusan Arbitrase Nasional Oleh Pengadilan Negeri", Jurnal Cita Hukum. Volume II No. 2.

[9] Mertokusumo, Sudikno. (2005), "Faktor-faktor Yang Mempengaruhi Dan Menghambat Pelaksanaan Putusan Hakim (eksekusi) dalam Perkara Perdata", Majalah ilmiah Ilmu Hukum Jatiswara, Fakultas Hukum Universitas Mataram, Vol.20, No.3, Juli.

[10]Prabowo, Tri Ari dan Nazriyah, R. (2017) "Pembatalan Putusan Arbitrase oleh Pengadilan dalam Putusan Mahkamah Konstitusi Nomor 15/PUU-XII/2014”, Jurnal Konstitusi, Volume 14, Nomor 4, Desember.

[11]Putnado, Muhammad Gakhairi. (2017), "Kajian Hukum Pembatalan Putusan BPSK Nomor 11/PTS-BPSK/BKT/X/2015 Atas Upaya Hukum Keberatan Oleh Pihak Pelaku Usaha (Studi Kasus Putusan Pengadilan Negeri Bukittingi Nomor 24/PDT.SUS-BPSK/2015/PN.BKT)", Diponegoro Law Journal, Volume 6, Nomor 2.

[12]Rosita. (2017), “Alternatif Dalam Penyelesaian Sengketa (Litigasi Dan Non Litigasi)", Al-Bayyinah of Islamic Law, Volume IV Nomor 2, Desember, http://dx.doi.org/10.35673/al-bayyinah.v1i2.20.

[13] Siallagan, Gabriel. (2013) "Analisis Yuridis Upaya Keberatan Terhadap Putusan Badan Penyelesaian Sengketa Konsumen Dalam Kaitannya Dengan Perlindungan Konsumen"Jurnal Nestor Magister Hukum, Volume 3 Nomor 5.

[14] Wulandari, Bernadetta T. (2006), "BPSK Sebagai Alternatif Upaya Penegakkan Hak Konsumen Di Indonesia”, Gloria Juris, Volume 6 Nomor 2.

[15]Adminbpl, "Ini Alasan Penyelesaian Sengketa Arbitrase Menjadi Populer Di Dunia Bisnis", https://bplawyers.co.id/2016/08/29/penyelesaiansengketaarbitrase/. 